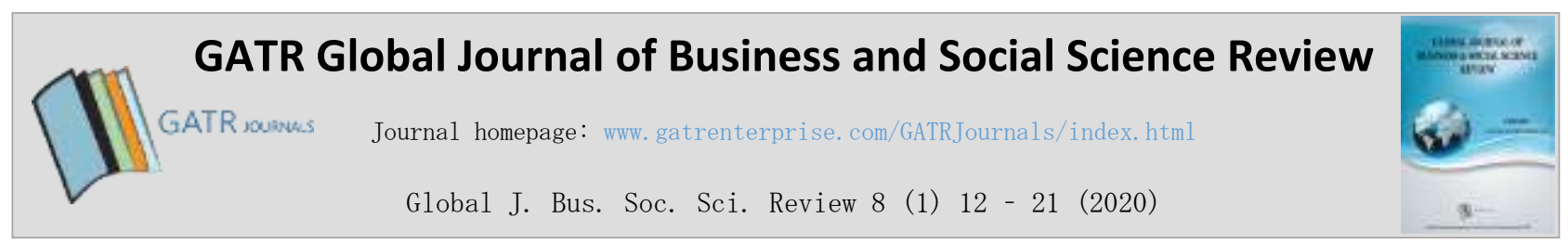

\title{
Innovation in Delivering Public Health Service: Practice In Banyuwangi Regency - Indonesia
}

\author{
Anugerah Yuka Asmara ${ }^{1 *}$ and Amy Yayuk Sri Rahayu ${ }^{2}$ \\ ${ }^{1}$ Centre for Science-Technology-Innovation Policy and Management (PPKMI) -Indonesian Institute of Sciences (LIPI), \\ 12710, Jakarta, Indonesia \\ ${ }^{2}$ Faculty of Administrative Science - University of Indonesia (FIA-UI), 16424, Depok, Indonesia
}

\begin{abstract}
Objective - The objective of this study is to elaborate that innovation in public sector organizations (PSOs), especially in delivery of public service, is not mostly determined by top management in the public sector. A new paradigm of public management has led to the creation of a new cooperation scheme across actors in forms of co-design, coproduction, and collaboration between public service supplier(s) and users. In the public sector, interconnectedness among actors to make innovation in public service delivery is rare.

Methodology/Technique - The method of this research is a case study of 3 different health agencies (Puskesmas) in the Regency of Banyuwangi, East Java Province, Indonesia. All three Puskesmas agencies represent 3 different cultures influencing the practice of innovation in public health service delivered by them.

Finding - The findings reveals that the practice of innovation in public service delivery within new paradigm of public management by which interconnectedness between public agency and local communities has occured. The findings of this study show that there is strikingly different impact of innovation delivered by the 3 Puskesmas agencies.

Novelty - This study contributes to existing literature on public or organizational management that culture values of local communities as target groups cannot be neglected in implementing innovation in PSOs.

Type of Paper: Empirical.

Keywords: Innovation, Public Service, Health Service, Banyuwangi, Indonesia.

Reference to this paper should be made as follows: Asmara, A. Y; Rahayu, A.Y.S. (2020). Innovation in Delivering Public Health Service: Practice in Banyuwangi Regency - Indonesia, Global J. Bus. Soc. Sci. Review, 8(1): $12-21$. https://doi.org/10.35609/gjbssr.2020.8.1(2)
\end{abstract}

JEL Classification: H80, H89.

\section{Introduction}

Innovation is the newness of things which are used by end users (Miles, 2013), which was firstly used in business sector organizations (BSOs) (Borins, 2001) and is now broadly used in public sector organizations (PSOs) (Joyce, 1998; Horton, 2008; Gault, 2018).

\footnotetext{
* Paper Info: Revised: January 13, 2020

Accepted: March 31, 2020

* Corresponding author: Anugerah Yuka Asmara

E-mail: a.yuka.asmara@gmail.com

Affiliation: PPKMI - Indonesian Institute of Sciences (LIPI), Indonesia
} 
Innovation practices in PSOs is rather different to innovation in BSOs. Hartley (2013) states that innovation practices in PSOs can be adopted and duplicated to other public organizations, while in BSOs, innovation is a confidential practice of each frms or business units to keep inside of their business activities. Fuglsang and Sunbo (2005), Lynn Jr (2013) and Hartley (2013) state that innovation in PSOs is not limited to efficiency or the economic goals of the organization, but also on the socio and political goals as well. According to Horton (2008) and Hartley (2013), the main goal of innovation in PSOs is to increase public service because the public agencts are accountable to the public and politicians.

Enlargement of innovation in PSOs identifies that innovation is not merely the result of R\&D acitivites in firms/R\&D institutions (see Jyoti et. al., 2006). Thus, innovation varies in many ways such as new service, new delivery service, new organization, new policy, new concepts, and new systems (Windrum, 2008). Whatever type of innovation is used in PSOs, the root of innovation theory is that innovation involves various actors (Dodgson, 2000; de Bes \& Kotler, 2015; Schot \& Steinmueller, 2018), through complex interaction among interrelated actors (Martin, 2010; Chaminade \& Edquist, 2010; de Bes \& Kotler, 2015).

Studies of innovation in PSOs concerning public service delivery are common (see Joyce, 1998; Albury, 2011; Osborne, 2013; Sousa et. al., 2015; Yip \& Mckern, 2016; Bertot et. al., 2016). Studies of advancing innovation in PSOs or public service delivery focused on suppliers side of innovation such as on the role of public leaders, civil servant motivation, innovation capacity of human resource management, organization capability and strategies to innovate (see Albury, 2011; Cochran, 2014; Sousa et. al., 2015; OECD, 2017; Grotenbreg \& van Buuren, 2018). Nowadays, a new paradigm of innovation in public service delivery is identified as a complex interaction of multiactors which leads to governance practice. Governance is meant as co-creation, co-design, collaboration between public agencies as innovation suppliers and citizen as innovation users (Gurtoo \& Williams, 2015; Arundel et. al., 2019). This is also known as "co-evolutionary process" (Scopula \& Zanfei, 2016:237) or as "co-producton" (Osborne, 2013:65). Society is a very important element in public service context (Daglio et. al., 2015). Notwithstanding, current studies of innovation in PSOs is rarely discussed (see Scopula \& Zanfei, 2016).

The interconnectedness between public agencies and its users is critical in yielding innovation practice of public sector organizations. This discourse is adjacent with elements of new paradigm of public service delivery. Gurtoo and Williams (2015) assert that the new paradigm of public service delivery is composed to input elements, moderator elements, and outcome elements. They determine innovation practice delivered by three public health care units (Puskesmas) in Banyuwangi Regency, at East Java Province, Indonesia, as the most innovative local government at regency level in Indonesia (see Asmara \& Rahayu, 2019). According to The Indonesian Ministry of Administrative and Bureauractic Reform (KemenPAN \& RB), there are 14 public innovative awards received by Regency of Banyuwangi during 2012-2019 at national level, of total 14 awards, 7 are in public health service (extracted from KemenPAN \& RB, 2019).

One of the prominent health programs in the Regency of Banyuwangi is to minimize the death rate of mothers and infants since 2014. Besides the urgent health matter in Banyuwangi area, that program is the national mandatory program of the Indonesian Ministry of Health (Kemenkes) that needs to be resolved immidiately (Pemkab-Banyuwangi, 2016; 2019). Technically, all public health programs are delivered by the lowest level unit of public health care service agency (Puskesmas) at district area. To solve those problems, innovation in public health service is needed by Puskesmas.

"Public sector innovation uses new approaches to create public value for individuals and for society" (OECD, 2017:14). Therefore, 3 multiple cases of Banyuwangi's Puskesmas are presented in this study namely Puskesmas-Sempu, Puskesmas-Wongsorejo, and Puskesmas-Licin in minimizing the death rate of mothers and infants in each district of Puskesmas. These 3 agencies become representative of public value of society in the Regency of Banyuwangi mainly consisting of Javanese society culture in working area of Puskesmas-Sempu, Maduranese society culture in working area of Puskesmas-Wongsorejo, and Osing society culture in working area of Puskesmas-Licin. 
This study contributes to existing literature on public organizations and management including innovation in PSOs in 2 ways. First, innovation in PSOs, in comparison to BSOs, has similiarity in supply and demand. Interconnectedness of public agencies on the supply side and local communities on the demand side is substantial to make innovation implementable. Second, we stress the imporatnce of cultural values embedded in local communities in delivering innovation of public service. It is rarely by reason of existing studies of innovation in PSOs is strongly by a public leader.

Expecting that all 3 cases can provide new insight related to interconnectedness between centres of public health care as suppliers side and local communities as users side in terms of innovation of public health service delivery. Therefore, the following questions are posed in this study:

What forms of innovation are the 3 Puskesmas implementing to minimize the death rate of mothers and infants in each district?

How do these 3 Puskesmas units implement programs aimed at minimizing the death rate of mothers and infants in each district?

How does the involvement of local communities with the implementation of programs minimize the death rate of mothers and infants in each district?

The rest of this paper is organized as follows. A literature review of innovation in public sector organizations (PSOs) and appropriate elements of new public service concept are provided in section 2. Section 3 describes the research method using case study as an analytical tool to elaborate the findings. The results of this study are reported in section 4. Section 5 concludes this paper and provides key factors in implementing public health service in Banyuwangi Regency.

\section{Literature Review}

\subsection{Innovation in Public Sector Organizations (PSOs)}

Innovation in public sector organizations (PSOs) is based on a basic definition of innovation coined by Schumpeterian's concept (Albury, 2011; Valkama et. al., 2013), as a new means to achieve public goals (OECD, 2017) and then widely reinforced by Oslo-Manual that innovation practice comprises 4 (four) categories namely new products, new processes, new organization types, and new marketing or business models (OECD-Eurostat, 2005; Djellal et. al., 2013; Arundel et. al., 2019). In PSOs, innovation is the introduction of all new public services that are newness in organization forms, insight, management, and skill capacity (Osborne and Brown, 2005), it should not be totally new, but can be adopted from previously existing newness (Rogers, 1995), due to it inclusiveness (Roland, 2017).

Innovation in PSOs is a wider term rather than in business sector organizations (BSOs) consisting of 4 new categories as coined by OECD-Eurostat (2005). Innovation is not restricted on a single newneess such as innovation on technology, service, and organization (Pekkarinen et. al., 2011). In PSOs, innovation comprises such as new service (providing public goods and services), new delivery service (how public service is delivered to customers ), new organization (new internal business process or mechanism) (Windrum, 2008; Hartley, 2013; Gault, 2018), new communication/marketing (new method to introduce public service products) (Gault, 2018), new policies (new governmental direction, procedures, programs, etc.) (Windrum, 2008; Hartley, 2013), new concepts (new vision-mission, new strategies, new outlook), new systems (new interaction pattern to other organizations) (Windrum, 2008), new governance (new institution and procedurs leading to policy) and new rhetoric (new symbol, languange, concept) (Hartley, 2013).

Innovation in delivering public service is critical and is at the heart of the main duty and responsibility of a government agency. We argue that innovation in delivering public service is not separated from other forms of innovation in PSOs that can be conducted simultaneously and continuously. It is essential to create 
innovation in concept, innovation in policy, innovation in organization, and even innovation in governance before implementing public service innovation.

\subsection{New Elements of Public Service Delivery and Its Innovation}

Public services are activities conducted by public agencies in producing as well as providing public goods to citizens (Farnham \& Horton, 1996). Delivering public service is a mandatory objective of each PSOs (Bertot et. al., 2016) to fulfill public interest (Ko \& Han, 2013) as well as to make "fairness of social equity" (Shafritz et. al., 2013). Over the past decade, the concept of public service has shifted from traditional way or weberian system to new paradigm identified by emergence of new public management (NPM) (Stewart, 2009; Demircioglu \& Audretsch, 2017). Public service is directed to not only by the result of politics or rigid procuders as a bureaucracy system of centralised delivery, but also to accomodate public demands through increase of public participation in determining what those need (Stewart, 2009; Gurtoo \& Williams, 2015). Therefore, capability or efforts of public agencies to deliver public service through the creation of new ideas and ways to respond to the needs of citizens in a changing context is necessary (OECD, 2017) including cooperation and co-production with private sectors (Stewart, 2009; Osborne, 2013; OECD, 2017).

The new paradigm of public service delivery includes the involvement of public and multiple actors simultaneously among public authorities, citizens, and public service providers (Gurtoo \& Williams, 2015). There are 5 prominent dimensions of new paradigm of public service delivery as follows:

"Multiactor perspective: the multiple-agency involvement in delivery models; Sociopolitical networks: the overarching relationships within the society which is localized and decentralized; The coordination networks: required are structural as well as technological. The implementation of service hinges on the right alignment of these two networks among themselves and between each other; contract governance: the obligations and duties shared by the multiple agencies of a public delivery system citizen-led governance: management of increased engagement of individuals and nongovernmental organizations in the policy dialogue" (Gurtoo \& Williams, 2015, p. 272-273).

Co-creation between supplier(s) and users involving multiple actors is a governance mechanism to determine the extent to which it can create and implement innovation in public service delivery (Gurtoo \& Williams, 2015; Arundel et. al., 2019). In the new paradigm, delivering public service needs to change existing business process to be efficient and responsive to citizens (Lane, 2000), but these practices differ to services in the private sector (Sousa et. al., 2015), due to the presence of political accountability of policy makers (Lynn Jr. 2013; Hartley, 2013; Batley \& Mcloughlin, 2015). Gurtoo and Williams (2015: 275) propose 3 elements of delivering innovative, competitive, efficient, and cost-effective public service delivery namely "takes into account the requirements of the public service (inputs), the wide range of risks and uncertainties associated with the service (impacts), and the implementation conditions and regulations which are special considerations (moderators) for efficient operations" (Table 1).

Table 1. Three Elements of New Public Service Delivery Model

\begin{tabular}{|l|l|l|}
\hline \multicolumn{1}{|c|}{ Input Elements* } & \multicolumn{1}{|c|}{ Moderator Elements* $^{*}$ Impact Elements** } \\
\hline $\begin{array}{l}\text { Social elements, constraints, resources, } \\
\text { technology, behaviour of agencies, } \\
\text { behaviour of the population }\end{array}$ & $\begin{array}{l}\text { Evaluation parameters, market, degree of } \\
\text { increased, integration level, accountability, } \\
\text { transferability of experience }\end{array}$ & $\begin{array}{l}\text { Outcome or benefit received } \\
\text { in long term of an activity } \\
\text { and/or activities }\end{array}$ \\
\hline
\end{tabular}

Source: *Gurtoo and Williams (2015:276), **Interpreted from Roker (2005:124)

Innovation in public service delivery is not a single mechanism. It must be supported by other innovative ways such as communication and marketing innovation (Gault, 2018) or systemic innovation (Windrum, 
2008). The most important aspect of this new paradigm of public service delivery is governance (Hartley, 2013) and related to policy innovation and rhetoric/concept innovation (Windrum, 2008; Hartley, 2013).

We argue that innovation in public service is a must in the current decade due to the high demand of citizens. Government agencies cannot innovate by themselves, involvement of society and non-government organizations (NGOs) are critical to innovation in public service. Innovation of public service delivery is supported by 3 elements comprising supplier elements (input elements), intermediary elements (moderator elements), and outcome elements (impact elements). Co-creation is necessary to realize innovation in delivering public service, thus, innovation in PSOs is crowded work.

\section{Research Methodology}

This research is a post-positivistic apprroach using multiple case study methods of 3 centres of the lowest level unit of public health care service agencies (Puskesmas) in the Regency of Banyuwangi namely, Puskesmas-Sempu, Puskesmas-Wongsorejo, and Puskesmas-Licin in minimizing the death rate of mothers and infants. By using multiple case studies, the phenonema can be revealed through more than a case to make field finding robust with specific and similia criteria (Yin, 2003). To apply it, the program of minimizing death rate of mother and infants conducted by each Puskesmas are compared and analysed according to new elements of public service delivery and its innovation coined by Gurtoo and Williams (2015).

This study was conducted between early Januay 2019 and the end of October 2019 (10 months) consisting of 2 time periods sequentially. In the first period between January-May 2019, data was collected from 3 districts in Regency of Banyuwangi namely, district of Sempu, district of Licin, and district of Wongsorejo. Data was collected during deep interviews of 28 key informants consisting of 20 persons from the local Government of Banyuwangi including officials at 3 Puskesmas units, and 8 citizens occupying the 3 districts. In addition, documentation is also used to reinforce the field data support. In the second period between JuneOctober 2019, field data was analysed by tracing various literature to complete the field finding results.

\section{Results and Discussion}

\subsection{Programs of Minimizing Death Rate of Mothers and Infants in each Puskesmas}

The Puskesmas-Sempu is located in Sempu district, south-west of Banyuwangi area and delivers public health care services to 3 villages namely Sempu, Jambewangi, and Tegalarum. The Puskesmas-Wongsorejo is located in the north of Banyuwangi area that delivers public health care services to 5 villages namely, Wongsorejo, Bangsring, Bengkak, Alasbuluh, and Alasrejo. The last, the Puskesmas-Licin is located in Licin district, west of Banyuwangi area and delivers public health care services to 8 villages including Licin, Tamansari, Segobang, Banjar, Jekun, Pakel, Kluncing, and Gumuk.

Each Puskesmas has a different name for the program aimed at minimizing the death rate of mothers and infants rooted from local knowledge and specific means used in achieving the program goals. The Puskesmas-Sempu has program of "Sakina", an abbrevation of Stop Angka Kematian Ibu dan Anak, established since 2014 in the working area of Puskesmas-Sempu. The Puskesmas-Wongsorejo has program of "Batu-Akik", an abbrevation of Bersama Turunkan Angka Kematian Ibu dan Anak, established in 2015 in the working area of Puskesmas-Wongsorejo. Lastly, the Puskesmas-Licin has program of "Ider-Bumi", an abbrevation of Intip Dengan Ramah Bersama Untuk Mencari Solusi, established since early 2019 in the working area of Puskesmas-Licin.

\subsection{Implementation of Sakinah, Batu-Akik, and Ider-Bumi}

Referring to Gurtoo and Williams (2015), implementation of Sakina, Batu-Akik, and Ider-Bumi, consists of 3 elements namely: input, moderator, and impact. In the case of Puskesmas-Sempu, the input elements are 
social elements comprising of importance of health for local people, network of social organizations, political support of Banyuwangi's Regent, resources comprising of generating as many as innovative health service programs called as"Puskesmas-Berhati-MP3", closeness between official staff to local communities, technology (infomation technology/IT), behaviour of agency comprising of improvement of medical expertise or staff, creation of new ideas, local value-based leadership style and management, behaviour of population comprising of respecting to one persons to another person's, particulary to elder persons or prominent figures, being open to be involved with outsiders, following the community agreement, and constraints comprising of less incentive for innovators, limited health mobile infrastructures, the mountanious and scattered hinterland area, less-educated communities.

Moderator elements are urgency to reduce the death rate of mothers and infants, accountable program to local and central government, interlinked actions among Puskesmas-Sempu to non-profit organizations and cross-sector public agencies, motivation pushed from public needs and initiative by Puskesmas's officials themselves, involvement of village women cadres and mobile vegetables sellers (mlijo), Whats Application (WA) as a communication media across sector agencies including women cadres and mlijo, concordance with existing culture, and the supporting regulations of program. The impact of this program is zero death rate of mother and infants since 2015 to present.

In the case of Puskesmas-Wongsorejo, the input elements are social elements (comprising importance of health for local people, political support of Banyuwangi's Regent), resources (comprising improvement of as many as innovative health programs through "Puskesmas-Berhati-MP3", tourism area), technology (infomation technology/IT), behaviour of agency (comprising improvement of medical expertise of staffs, pushed to innovate), behaviour of population (comprising strong religious-driven conducts, following the community agreement), and constraints (comprising less incentive for innovators, limited mobile health infrastructures, coastal and hinterland area, less-educated communities).

The moderator elements are reducing the death rate of mothers and infants is part of priorities program like wiping off dengue mosquitos, increasing children nutrition, and other programs at PuskesmasWongsorejo, involvement of village women cadres is not fully devoted on reducing mother death rate and infants, but to other health care services, Whats Application (WA) as communication media cross-sector agencies in many public care services, motivation is pushed from mandatory direction of Local Government of Banyuwangi, and local regulations that support all health care activities. The impact element of this program is existing, but there is no significant and wide outcome of this program to target groups of high-risk pregnant mothers in this district.

In the case of Puskesmas-Licin, input elements are social elements (comprising importance of health for local people, political support of Banyuwangi's Regent), resources (comprising generating as many as innovative health programs through "Puskesmas-Berhati-MP3", tourism area), technology (infomation technology/IT), behaviour of agency (comprising improvement of medical expertise of staffs, pushed to innovate, communicating with local figures), behaviour of population (comprising strong local tradition combined with religion-driven conducts, tends to tourism-motivated activities following the community agreement), and constraints (comprising less incentive for innovators, limited mobile health infrastructures, the mountanious and scattered area, less-educated communities).

The moderator elements are reducing the number of death rate mothers and infants is less priority rather than program of mental illness care and open defecation free (ODF), involvement of village women is not fully devoted on minimizing the death rate among mothers and infants, Whats Application (WA) as communication media cross-sector agencies, motivation is merely pushed from mandatory direction of Local Government of Banyuwangi, and local regulations that support all health care activities. The impact element of this program is decline of neonatal newborn infants from 8 babies in 2018 to 3 babies in 2019.

\subsection{Involvement of Local Communties in implementing Sakinah, Batu-Akik, and Ider-Bumi}


Local community dwellings in working area of 3 Puskesmas units consisting of 3 different cultures namely, The Javanese culture in Sempu district, The Maduranese culture in Wongsorejo district, and The Osing culture in Licin district. Those cultural values are strikingly diverse in each district. Sempu is located in the southwest of the Banyuwangi area, Wongsorejo is located north of the Banyuwangi area, and Licin is located in the west-middle area of the Banyuwangi area. In the early phase, the death rate of mothers and infants is a big issue, but most local communities are reluctant to receive Puskesmas's programs in solving the issue. Rather, they strongly rely on traditional shaman(s) to solve it.

Each Puskesmas has a unique way to reduce death rate of her mother and infants according to governmental policies and its funding support, public issues or demands with local characteristics, and the capability of internal Puskesmas management. The 3 Puskesmas units employ and involve health cadres who are all women to assist Puskesmas duties in delivering daily public health care services. Sakina delivered by Puskesmas-Sempu has succesfully attracted wider involvement not only women cadres, but also vegetablesellers (mlijo) (Asmara \& Rahayu, 2019). In this district, local people are eagar to be widely involved in new public health care services initiated by Puskesmas-Sempu because they can receive positive benefits.

Batu-Akik is delivered by Puskesmas-Wongsorejo. In this matter, involvement of the wider community is limited, optimizing women cadres is a single way to deliver that program. In the Wongsorejo area, local people are dominated by Moslem culture with strong religious values, and they are actively involved in public health care services provided by prominent religiuos figure(s). Ider-Bumi is delivered by PuskesmasLicin focusing on optimizing involvement of women cadres and local bigwig. In this case, the local population is strongly connected to customs and tradition, and they prefer to do health programs driven by with local values strongly embedded in the area or concerned with tourism.

\section{Conclusion}

the elements of the within paradigm of new public management are influencing factors in delivering public service innovation. Input elements such as society, resources, technology, and constraints are similiar factors related to how innovation is delivered by public agencies. On the other hand, elements of behaviour of agency and population are different in each public agency. Three Puskesmas namely Sempu, Wongsorejo, and Licin in the Banyuwangi Regency are evidence of this practice.

Firstly, behaviour of agency are shown as leadership and management styles at the top structure of an organization. This factor is derived from supplier side of innovation. Secondly, behaviour of agency is shown as society cultural values from the user side of innovation, namely local society as target groups. Input elements influence pattern of moderator elements at each Puskesmas bridging the outcome of public health service. If input elemens are diverse, the moderator elements will adjust those elements at an early stage to improve the impact of innovation practices.

The involvement of woman cadres and local communities is integral to innovation in public health services. A limited number of official health staff at public health agencies is one of the primary reasons to innovate in PSOs. However, local communities are target groups of innovation, they are limited in knowledge capacity and access to outside networks (government and private agencies). Therefore, public agencies are a facilitator in making innovation provided that they consider local values embedded and adhered to by local communities.

\section{Acknowledgements}

The authors would like to thank the Faculty of Administrative Science (FIA) - University of Indonesia (UI) for providing a partial grant of funding for this research. 


\section{References}

\section{Journal articles}

Albury, D. (2011). Creating the Conditions for Radical Public Service Innovation. The Australian Journal of Public Administration, 70 ( 3), 227-235. https://doi.org/10.1111/j.1467-8500.2011.00727.x

Arundel, A., Bloch, C., \& Ferguson, B. (2019). Advancing Innovation In the Public Sector: Aligning Innovation Measurement with Policy Goals. Research Policy, 48, 789-798. https://doi.org/10.1016/j.respol.2018.12.001

Batley, R. \& Mcloughlin, C. (2015). The Politics of Public Services: A Service Characteristics Approach. World Development, 74, 275-285. https://doi.org/10.1016/j.worlddev.2015.05.018

Bertot, J., Estevez, E., \& Janowski, T. (2016). Universal and Contextualized Public Services: Digital Public Service Innovation Framework. Government Information Quarterly, 33 (2), 211-222. DOI: 10.1016/j.giq.2016.05.004

Borins, S. (2001). Encouraging Innovation in the Public Sector. Journal of Intellectual Capital, 2 (3), 310 319. https://doi.org/10.1108/14691930110400128

Demircioglu, M. A. \& Audretsch, D. B. (2017). Conditions for Innovation in Public Sector Organizations. Research Policy, 46, 1681-1691. https://doi.org/10.1016/j.respol.2017.08.004

Djellal, F., Gallouj, F., \& Miles, I. (2013). Two Decades of Research on Innovation in Services: Which Place for Public Services? Structural Change and Economic Dynamics, 27, 98- 117. 10.1016/j.strueco.2013.06.005ff. ffhalshs01133837

Fuglsang, L. \& Sundbo, J. (2005). The Organizational Innovation System: Three Modes. Journal of Change Management, 5 (3), 329-344

Gault, F. (2018). Defining and Measuring Innovation in All Sectors of the Economy. Research Policy, 47, 617-622. https://doi.org/10.1080/14697010500258056

Grotenbreg, S. \& van Buuren, A. (2018). Realizing Innovative Public Waterworks: Aligning Administrative Capacities in Collaborative Innovation Processes. Journal of Cleaner Production, 171, S45-S55. dx.doi.org/10.1016/j.jclepro.2016.08.128, hdl.handle.net/1765/93307

Joyce, P. (1998). Management and Innovation in the Public Services. Strategic Change, 7, 19-30. DOI: 10.1002/(SICI)1099-1697(199801/02)7:13.0.CO;2-H

Jyoti; B. D. K.; \& Deshmukh, S. G. (2006). Balance Scorecard for Performance Evaluation of R\&D Organization: A Conceptual Model. Journal of Scientific and Industrial Research, 65, 879-886. http://nopr.niscair.res.in/bitstream/123456789/4952/1/JSIR\%2065(11)\%20879-

886.pdf?utm_source=The_Journal_Database\&trk=right_banner\&id=1400490118\&ref=61e0e03534f65ac865152370a21 b8cfc

Ko, K. \& Han, L. (2013). An Empirical Study on Public Service Motivation of the Next Generation Civil Servants in China. Public Personnel Management, 42 (2), 191-222. https://doi.org/10.1177/0091026013487122

Pekkarinen, S., Hennala, L., Harmaakorpi, V.. \& Tura, T. (2011). Clashes as Potential for Innovation in Public Service Sector Reform. International Journal of Public Sector Management, 24 (6), 507-532. https://doi.org/10.1016/S22125671(15)01096-5

Roland, G. (2017). An Elaboration on Measures to Promote Institutional Innovation, Transformation, and inclusiveness to Enhance Public Service Delivery. Review Pub Administration Management, 5 (2), 1-4. DOI: 10.4172/23157844.1000220

Schot, J. \& Steinmueller, W. E. (2018). Three Frames for Innovation Policy: R\&D, Systems of Innovation and Transformative Change. Research Policy, 47, 1554-1567. https://doi.org/10.1016/j.respol.2018.08.011

Scupola, A. \& Zanfei, A. (2016). Governance and Innovation in Public Sector Services: The Case of The Digital Library. Government Information Quarterly, 33, 237-249. https://doi.org/10.1016/j.giq.2016.04.005

Sousa, M. de M., Ferreira, V. da R. S., Najberg, E., \& Medeiros, J. J. (2015). Portraying Innovation in the Public Service of Brazil: Frameworks, systematization and Characterization. R. Adm., São Paulo, 50 (4), 460-476. DOI: $10.5700 /$ rausp 1213

\section{Books}

de Bes, F. T. \& Kotler, P. (2015). Winning at Innovation: The A-to-F Model. New York, USA: Palgrave Macmillan. Lane, Jan-Erik. (2000). New Public Management. London, UK : Routledge. 
OECD. (2017). Fostering Innovation in the Public Sector. Paris, France: OECD Publishing.

OECD-Eurostat. (2005). Oslo Manual: Guidelines for Collecting and Interpreting Innovation Data. Paris, France: OECD Publishing.

Osborne, S. P. \& Brown, K. (2005). Managing Change and Innovation in Public Service Organizations. London, UK and New York, USA: Routledge.

Rogers, E. M. (1995). Diffusion of Innovations (Fourth Edition). New York, USA: The Free Press.

Shafritz, J. M.; Russell, E.W., \& Borick, C. P. (2013). Introducing Public Administration, Eighth Edition. Boston, USA: Pearson.

Stewart, Jenny. (2009). Public Policy Values. New York, USA: Palgrave Macmillan.

Yin, R. K. (2003). Case Study Research: Design and Methods, Third Edition. Thousand Oaks - California USA: SAGE Publications Incorporations.

Yip, G. S. and McKern, B. (2016). China's Next Strategic Advantage From Imitation to Innovation. Cambridge, Massachusetts, USA: The Massachusetts Institute of Technology Press.

\section{Book chapters in an edited book}

Chaminade, C. \& Edquist, C. (2010). Rationales for Public Policy Intervention in the Innovation Process: Systems of Innovation Approach. In R. E. Smits., S., Kuhlmann. \& P. Shapira (Eds), The Theory and Practice of Innovation Policy (An International Research Handbook) (pp. 95-114). Cheltenham, UK: Edward Elgar.

Dodgson, M. (2000). Policies for Science, Technology, and Innovation in Asian Newly Industrializing Economies. In L. Kim \&, R. R. Nelson (Eds), Technology, Learning, \& Innovation (pp. 229-268). Cambridge, UK: Cambridge University Press.

Farnham, D. \& Horton, S. (1996). Continuity and Change in the Public Services. In D. Farnham \& S. Horton (Eds), Managing People In The Public Services (p. 3-42). London, UK: Macmillan Press Limited.

Gurtoo, A. \& Williams, C. (2015). Public Service Delivery - An Integrative Framework. In A. Gurtoo \& C. Williams (Eds), Developing Country Perspectives on Public Service Delivery (pp. 271-287). New Delhi, India: Springer.

Hartley, J. (2013). Public and Private Features of Innovation. In S. P. Osborne \& L. Brown (Eds.), Handbook of Innovation in Public Services (pp. 44-59). Cheltenham, UK: Edward Elgar.

Horton, S. (2008). History and Persistence of An Idea and An Ideal. In J. L. Perry \& A. Hondeghem (Eds), Motivation in Public Management: The Call of Public Service (pp. 17-32). Oxford, UK: Oxford University Press.

Lynn, Jr., L. E. (2013). Innovation and Reform in Public Administration: One Subject or Two? In S. P. Osborne \& L. Brown (Eds.), Handbook of Innovation in Public Services (pp. 29-43). Cheltenham, UK: Edward Elgar.

Martin, B. R.( 2010). Inside the Public Scientific System: Changing Modes of Knowledge Production. In In R. E. Smits., S., Kuhlmann. \& P. Shapira (Eds), The Theory and Practice of Innovation Policy (An International Research Handbook) (pp. 25-50). Cheltenham, UK: Edward Elgar.

Miles, I. (2013). Public Service Innovation: What Messages from The Collision of Innovation Studies and Services Research? In S. P. Osborne \& L. Brown (Eds.), Handbook of Innovation in Public Services (pp. 72-88). Cheltenham, UK: Edward Elgar.

Osborne, S. P. (2013). A services-influenced approach to public service innovation? In Handbook of Innovation in Public Services. Edward Elgar Publishing.

Roker, D. (2005). Evaluating Projects Aimed at Supporting the Parents of Young People: "I didn't Learn Anything New, but ...”. In D. Taylor \& S. Balloch (Eds), The Politics of Evaluation: Participation and policy implementation (pp.119-131). Bristol, UK: The Policy Press.

Valkama, P., Bailey, S. J, \& Anttiroiko, A.-V. (2013). Contexts and Challenges of Organizational Innovation in Public Services. In P. Valkama, S. J. Bailey \& A.-V. Anttiroiko (Eds.), Organizational Innovation in Public Services Forms and Governance (pp. 3-12). Hampshire, UK: Palgrave Macmillan.

Windrum, P. (2008). Innovation and Entrepreneurship in Public Services. In P. Windrum \& P. Koch (Eds.), Innovation in Public Sector Services: Entrepreneurship, Creativity and Management (pp. 3-20). Cheltenham, UK: Edward Elgar. 


\section{Thesis}

Cochran, J. P. (2014). Assessing the Relationship between Leadership and Innovation in the Public Sector (A Dissertation) Presented in Partial Fulfillment of the Requirements for the Degree Doctorate of Education, Grand Canyon University, Phoenix, Arizona, USA. Published by ProQuest LLC (2014).

\section{A conference}

Daglio, M., Gerson D., \& Kitchen H. (forthcoming, 2015). Building Organisational Capacity for Public Sector Innovation. Background. Paper prepared for the OECD Conference "Innovating the Public Sector: from Ideas to Impact", Paris-France, 12-13 November 2014. Retrieved from https://www.oecd.org/innovating-the-publicsector/Background-report.pdf.

\section{Proceedings:}

Asmara, A. Y. \& Rahayu, A. Y. S. (2019). Sustaining Innovation on Public Health Service by Building Creative Culture in Rural Areas: Case on Program of Pemburu-Bumil-Resti at Banyuwangi Regency - Indonesia. IOP Conference Series: Earth and Environmental Science 328012034 (p 1-8). DOI: 10.1088/1755-1315/328/1/012034.

KemenPAN \& RB. (2019). Sistem Informasi Pelayanan Publik (In Indonesian). Retrieved from https://sinovik.menpan.go.id/index.php/welcome).

Regency-Banyuwangi. (2016). Regional Medium Term Plan (RPJMD) of Banyuwangi Regency 2016-2021 (Indonesian). Retrieved from https://www.banyuwangikab.go.id/media/doc/edoc/RPJMD.pdf.

Regency-Banyuwangi. (2019). Report of Responsibility (LKPJ) of Banyuwangi Regency 2018. Banyuwangi: Government of Banyuwangi Regency (In Indonesian). 